\title{
Effects of ammonia and nitrite on food consumption of the Amazon River prawn Macrobrachium amazonicum (Heller, 1862) postlarvae
}

\author{
${\text { Bruno Ribeiro de } \operatorname{Campos}^{1}{ }^{(\mathbb{D}} \text {, Rafael Ortiz Kracizy }{ }^{1,3}(\mathbb{D}) \text {, Plínio Schmidt Furtado }}^{1}$ \\ Izabel Volkweis Zadinelo ${ }^{2} \mathbb{D}$ \& Eduardo Luis Cupertino Ballester ${ }^{1,2,3}$ \\ ${ }^{1}$ Prawn Culture Laboratory, Aquaculture and Sustainable Development Post-Graduation Program \\ Federal University of Paraná, Palotina, PR, Brazil \\ ${ }^{2}$ Aquaculture and Sustainable Development Post-Graduation Program \\ Federal University of Paraná, Palotina, PR, Brazil \\ ${ }^{3}$ Prawn Culture Laboratory, Zoology Post-Graduation Program \\ Federal University of Paraná, Curitiba, Brazil \\ Corresponding author: Eduardo Luis Cupertino Ballester (elcballester@yahoo.com.br)
}

\begin{abstract}
Experiments were carried out to study the effects of ammonia and nitrite on food consumption of Macrobrachium amazonicum postlarvae. Postlarvae (average weight of $0.0625 \mathrm{~g}$ ) were exposed during 21 days to four concentrations of total ammonia $\left(0,1.05,2.1\right.$ and $4.2 \mathrm{mg}$. $\left.\mathrm{NH}_{3}+\mathrm{NH}_{4}{ }^{+} \mathrm{L}^{-1}\right)$ and four concentrations of nitrite $\left(0,0.075,0.15\right.$ and $\left.0.30 \mathrm{mg} \mathrm{N}-\mathrm{NO}_{2}^{-} \mathrm{L}^{-1}\right)$. After the exposure period, six prawns per treatment were maintained individually in $250 \mathrm{~mL}$ experimental units to analyze the food consumption as a function of the amount of food offered and the leftovers during a $24 \mathrm{~h}$ period. The food consumption presented significant alterations for prawns exposed to all nitrite concentrations and at concentrations of twice the recommended safety level for total ammonia. According to the results obtained, high concentrations of total ammonia and nitrite affect the food consumption of M. amazonicum adversely, influencing the species performance in culture systems.
\end{abstract}

Keywords: Macrobrachium amazonicum; water quality; nitrogenous compounds; nutrition; aquaculture

The Amazon River prawn, Macrobrachium amazonicum (Heller, 1862), has shown great aquaculture potential in subtropical and tropical regions (MoraesValenti \& Valenti 2010, Marques \& Moraes-Valenti 2012). However, environmental factors are considered determinants for successful prawn cultivation (Boyd \& Tucker 2012), and the development of modern aquaculture techniques led to the intensification in cultures of different species. There is an increasing trend in generating nitrogen compounds in these systems (Ballester et al. 2017).

In closed systems, especially in a modern hatchery, nursery, and grow-out systems that use water recirculation and high stocking densities, there is an accumulation of inorganic compounds, especially ammonia (Ballester et al. 2017), and nitrite (Furtado et al. 2016). These compounds are commonly related to the mortality of crustaceans in production systems; ammonia non-ionized form is demonstrably toxic (Armstrong et al. 1978) and influences negatively growth, feeding, survival, and susceptibility to diseases and parasites in prawns and other aquatic organisms (Daniels et al. 1992, Mugnier \& Justou 2004). Nitrite is a common toxic substance in culture systems, and the stress may affect hemocyanin synthesis and energy metabolism, resulting in the prawn's death (Li et al. 2019). Moreover, even if they do not cause mortality, they can directly affect growth and food consumption (Tomasso 1994, Campos et al. 2013, Maicá et al. 2018).

In rearing systems, nitrogen residues are common pollutants of the environment, with the excretion of organisms and degradation of food waste being the main sources of these substances (Boyd \& Tucker 2012). Diets used in aquaculture contain high protein levels and, as they are digested or degraded, the release of nitrogen compounds increases (Tomasso 1994). Ni- 
trogen compounds occur naturally in aquatic systems; however, if concentrations reach high levels, they may cause mortality or affect the growth of reared organisms (Boyd \& Tucker 2012).

Knowledge about food consumption is fundamental for food management to avoid excessive administration, which compromises water quality and insufficient supply of food that affects growth (Soares et al. 2005). Although studies have shown that food consumption varies according to the weight of prawns, different results among species and experimental conditions have been described (González-Peña et al. 2002, Campos et al. 2013, Maicá et al. 2018).

Prawn farms have used feed trays to reduce feed costs and maintain adequate water quality for the development of farmed organisms rather than following feeding tables. However, such practice does not prevent the detriment of water quality, and, in both cases, it is essential to know how water quality influences food consumption (Wasielesky Jr. et al. 2003, Campos et al. 2013). Therefore, this study aimed to evaluate the effects of total ammonia and nitrite on the food consumption of M. amazonicum postlarvae.

The experiment was carried out at the Laboratory of Prawn Culture, located at the Federal University of Paraná - Palotina Sector (UFPR by its acronym in Portuguese), and experimental organisms were obtained from the Aquaculture Center of UNESP CAUNESP / Jaboticabal.

M. amazonicum postlarvae (average weight of $0.0625 \mathrm{~g}$ ) were exposed during 21 days to four concentrations of total ammonia (control: 0; A: 1.05; B: 2.1; and $\mathrm{C}$ : $4.2 \mathrm{mg} \mathrm{NH}_{3}+\mathrm{NH}_{4}{ }^{+} \mathrm{L}^{-1}$ ) and four concentrations of nitrite (control: 0; D: 0.075; E: 0.15; and F: $0.30 \mathrm{mg} \mathrm{N}-\mathrm{NO}_{2}{ }^{-} \mathrm{L}^{-1}$ ). These values corresponded to control, half the safety level, safety level, and twice the safety level, as determined by Dutra et al. (2016a,b). The total ammonia levels were obtained by adding appropriate volumes of the stock solution of $\mathrm{NH}_{4} \mathrm{CL}$ $\left(1000 \mathrm{mg} \mathrm{L}^{-1}\right)$. Nitrite levels resulted from the addition of appropriate volumes of the stock solution of $\mathrm{NaNO}_{2}$ (250 $\mathrm{mg} \mathrm{L}^{-1}$ ).

After the chronic exposure period, the individual food consumption of six postlarvae, randomly selected from each treatment, was analyzed. Prawns were individually placed in $250 \mathrm{~mL}$ containers with the respective solutions of nitrogenous compounds; they were kept for $24 \mathrm{~h}$ without food. After this period, the media was completely renewed with the corresponding solutions of nitrogenous compounds to keep the total ammonia and nitrite concentrations at the required levels for each experiment. Prawns were fed with a preweighed commercial diet $(40 \%$ crude protein, $8 \%$ crude fat, $600 \mu \mathrm{m}$ pellets), and the feeding rate was $10 \%$ of the prawn biomass. During the experimental period, the following water quality parameters were monitored: dissolved oxygen (Oximeter, Alfakit, AT 160), temperature (Thermometer, digital Inconterm), and $\mathrm{pH}$ (pHmeter, Luca, 210). Total ammonia concentrations were checked by the colorimetric indophenol method (Koroleff 1976), and nitrite concentrations were determined by the colorimetric method of the Griess reaction (Baumgarten 1996).

After $24 \mathrm{~h}$, the experimental media were siphoned and filtered in a $30 \mu \mathrm{m}$ mesh, which was subsequently washed to eliminate feces remains. The feed remains were scraped and placed on laminated paper and then oven-dried at $60^{\circ} \mathrm{C}$ until reaching constant weight (Campos et al. 2013).

Five samples of known weight were placed in an oven at $60^{\circ} \mathrm{C}$, until reaching constant weight, to determine the percentage of dry matter of the commercial diet used in the experiment, using a digital electronic scale (AY220, Marte ${ }^{\circledR}$, precision of $0.01 \mathrm{~g}$ ). Samples were weighed again, and humidity was determined by the difference between the feed weight before and after drying. Diet leaching was determined in five replicate samples in glass beakers without prawns and with constant aeration. A known feed weight was used, and after $24 \mathrm{~h}$, the experimental media were siphoned and filtered through a $30 \mu \mathrm{m}$ mesh. The feed remains were scraped and placed on laminated paper and then in an oven at $60^{\circ} \mathrm{C}$ until a constant weight was reached.

The dry matter consumption of each prawn was determined by the difference between the amount of feed initially provided and the leftovers, considering the initial moisture content, feed leaching, and losses during the siphoning and washing process. The dry matter consumption was calculated using the following formula (Campos et al. 2013):

DMC $=(($ Rprovided $\times 0.928)-$ Rdry $) \times 0.55 /$ weight of prawn

where: DMC: dry matter consumption ( $\mathrm{g}$ of feed $\mathrm{g}$ of prawn $^{-1} \mathrm{~d}^{-1}$ ); Rprovided; amount of feed provided; $0.928=92.8 \%=$ initial dry matter content of the feed; Rdry: amount of feed after drying; $0.55=55.0 \%=$ percentage of dry material after the leaching test.

At the beginning and end of the food consumption test, temperature (analog mercury thermometer), dissolved oxygen (AT 170 digital oximeter, Alfakit ${ }^{\circledR}$ ), and $\mathrm{pH}$ (Yellow Springs $\mathrm{pH}$ meter, $\mathrm{YSI}^{\circledR}$ ) were measured.

Results of water quality variables and prawn food consumption were tested for normality and homoscedasticity of data (Sokal \& Rohlf 2012). Since these 
Table 1. Mean \pm standard deviation of total ammonia (control, A, B and C) and nitrite (control, D, E and F) in the water of the treatments applied to analyze food consumption of Macrobrachium amazonicum postlarvae.

\begin{tabular}{lcc}
\hline & Treatment & $\begin{array}{c}\text { Concentration } \\
\left(\mathrm{mg} \mathrm{L}^{-1}\right)\end{array}$ \\
\hline \multirow{4}{*}{ Ammonia } & Control & $0.01 \pm 0.02$ \\
& $\mathrm{~A}$ & $1.05 \pm 0.12$ \\
& $\mathrm{~B}$ & $2.11 \pm 0.07$ \\
& $\mathrm{C}$ & $4.23 \pm 0.08$ \\
\hline \multirow{4}{*}{ Nitrite } & Control & $0.02 \pm 0.01$ \\
& $\mathrm{D}$ & $0.08 \pm 0.10$ \\
& $\mathrm{E}$ & $0.15 \pm 0.11$ \\
& $\mathrm{~F}$ & $0.30 \pm 0.26$ \\
\hline
\end{tabular}

assumptions were satisfied, data were subjected to OneWay ANOVA followed by Tukey's test $(\alpha=0.05)$.

During the food consumption test, the mean values \pm standard deviation of $\mathrm{pH}$, temperature $\left({ }^{\circ} \mathrm{C}\right)$, and dissolved oxygen $\left(\mathrm{mg} \mathrm{L}^{-1}\right)$ in the experimental units were: $8.22 \pm 0.08,26.8 \pm 0.3$, and $7.2 \pm 0.6$, respectively; no significant differences were found among treatments. Total ammonia and nitrite concentrations remained close to the concentrations desired for the chronic toxicity test (Table 1).

For M. amazonicum postlarvae exposed to total ammonia, food consumption ranged from 0.0133 to $0.0181 \mathrm{~g} \mathrm{~g}^{-1} \mathrm{~d}^{-1}$ (Fig. 1) and was affected by the highest ammonia concentration, with treatment $\mathrm{C}$ being significantly different $(P<0.05)$ compared to the others. For prawns exposed to nitrite, food consumption ranged from 0.0077 to $0.01690181 \mathrm{~g} \mathrm{~g}^{-1} \mathrm{~d}^{-1}$ and was significantly affected $(P<0.05)$ in all treatments when compared to the control; treatment $\mathrm{F}$ differed significantly from treatments D and E (Fig. 1).

Studies of food consumption are important to determine survival and growth in adverse conditions (e.g. when organisms are submitted to higher levels of nitrogen compounds). Most of the energy originating from food can be channeled for metabolism and survival, while a smaller part would be available for growth and reproduction (Wong et al. 1993).

The toxic effects of ammonia in postlarvae have been observed in several species of prawns. However, few studies reported these effects in M. amazonicum (Dutra et al. 2016a). In the present study, adverse effects were only observed with concentrations of twice the safety level of total ammonia for M. amazonicum. Previous studies with other species have shown reduced larval development (Mallasen \& Valenti 2005), higher mortality (Ostrensky \& Wasielesky Jr. 1995), and changes in physiological processes, such as higher oxy-
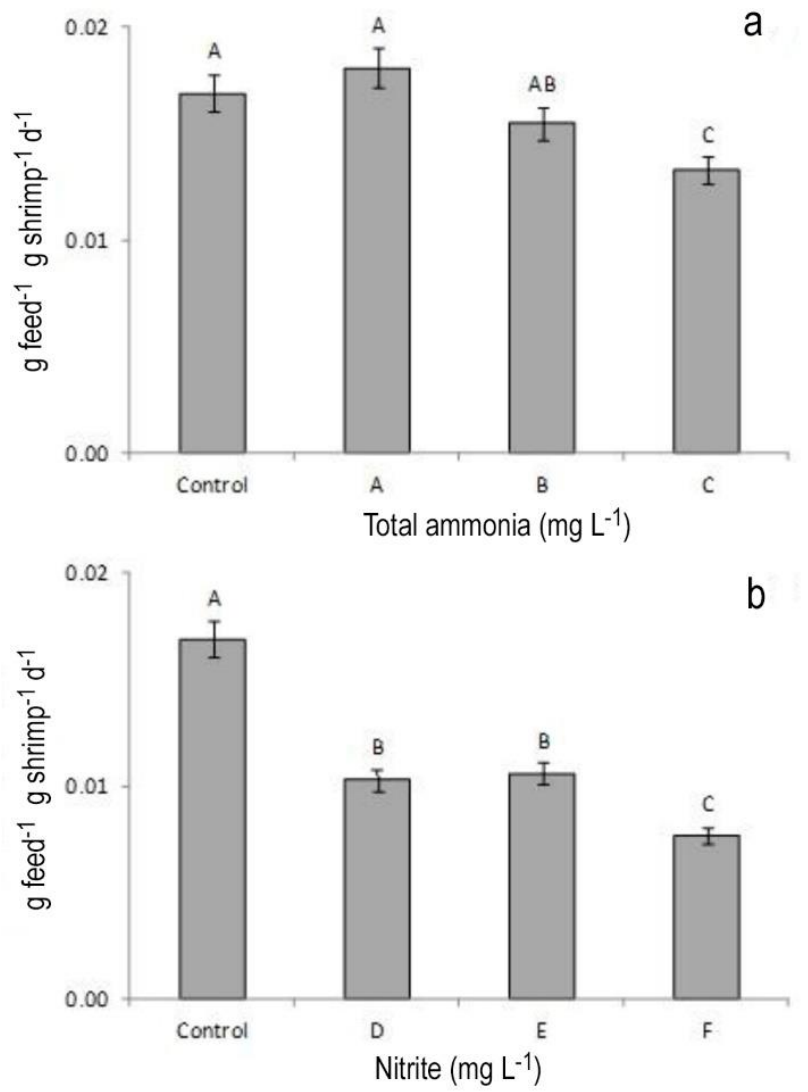

Figure 1. Means \pm standard deviation of food consumption of Macrobrachium amazonicum postlarvae exposed to different concentrations of a) total ammonia (A, B and C) and b) nitrite (D, E and F). Different superscript letters indicate statistical differences among treatments $(P<$ $0.05)$.

gen consumption (Barbieri 2010) and increase in nitrogen excretion (Romano \& Zeng 2013).

Additionally, at high concentrations, the nitrogen compounds may affect physiological processes of the cultured organisms such as osmoregulation and respiration, resulting in low food consumption, low specific growth rate, or even mortality of the prawns (Kuhn et al. 2010, Furtado et al. 2016). Wasielesky Jr. et al. (2003) found no adverse effects on food consumption, exposing Farfantepenaeus paulensis for 15 days at concentrations of $0.91,3.65$, and $7.30 \mathrm{mg} \mathrm{L}^{-1}$ of total ammonia. On the other hand, Miranda-Filho et al. (2009), analyzing the effect of ammonia on juveniles of the same species in pre-nursery and nursery phases during 75 days, observed a reduction in predation activity and growth.

Evaluating the effects of nitrite concentration on food consumption of F. paulensis, Wasielesky Jr. et al. (2003) observed a negative relationship even with only 15 days of exposure. In the present study, for prawns 
exposed to nitrite, food consumption was negatively affected in all treatments compared to the control. The action of nitrite on the respiratory pigments and the capacity of oxygen uptake and transport in the hemolymph could be responsible for the decrease in the food consumption rates since they reduce the aerobic metabolism of the prawns (Wasielesky Jr. et al. 2003). Therefore, lower food consumption may compromise growth rates and crop productivity, resulting in financial losses for producers.

As used in this experiment, nitrogen compounds affected food consumption rates of $M$. amazonicum postlarvae and may impact production results. It is also important to highlight that prawns were more sensitive to nitrite than ammonia concentrations.

\section{ACKNOWLEDGEMENTS}

Authors are grateful for the funding from the Authority for Studies and Projects of the Ministry of Science and Technology (FINEP) and the National Council for the Development of Science and Technology $(\mathrm{CNPq})$ for the Junior Postdoctoral Grant (PQ process: 420260/ 2017-0). Eduardo Luis Cupertino Ballester is thankful to the National Council for Scientific and Technological Development (CNPq) for the Research Productivity Grant (PQ process: 311456/2020-0), and Rafael Ortiz Kracizy thanks the Coordination for Improvement of Higher Education (CAPES) for the scholarship granted (Code 001).

\section{REFERENCES}

Armstrong, D.A., Chippendale, D., Knight, A.W. \& Colt, J.E. 1978. Interaction of ionized and un-ionized ammonia on short-term survival and growth of prawn larvae, Macrobrachium rosenbergii. Biological Bulletin, 154: 15-31. doi: 10.2307/1540771

Ballester, E.L.C., Marzarotto, S.A., Silva de Castro, C., Frozza, A., Pastore, I. \& Abreu, P.C. 2017. Productive performance of juvenile freshwater prawns Macrobrachium rosenbergii in biofloc system. Aquaculture Research, 48: 4748-4755. doi: 10.1111/are.13296

Baumgarten, M.G.Z. 1996. Manual de análises em oceanografia química. Furg, Rio Grande.

Barbieri, E. 2010. Acute toxicity of ammonia in white shrimp (Litopenaeus schmitti) (Burkenroad, 1936, Crustacea) at different salinity levels. Aquaculture, 306: 329-333. doi: 10.1016/j.aquaculture.2010.06.009

Boyd, C.E. \& Tucker, C.S. 2012. Pond aquaculture water quality management. Springer Science \& Business Media, New York.
Campos, B.R.D., Furtado, P.S., D'Incao, F., Wasielesky Jr., W. \& Poersch, L.H.D. S. 2013. Nitrogen compounds on food consumption of pink-shrimp Farfantepenaeus brasiliensis. Ciência Rural, 43: 2202-2207. doi: 10.1590/S0103-84782013005000136

Daniels, W.H., D’Abramo, L.R. \& Parseval, L.D. 1992. Design and management of a closed, recirculating "Clearwater" hatchery system for freshwater prawns, Macrobrachium rosenbergii (De Man, 1879). Journal of Shellfish Research, 11: 65-73.

Dutra, F.M., Forneck, S.C., Brazão, C.C., Freire, C.A. \& Ballester, E.L.C. 2016a. Acute toxicity of ammonia to various life stages of the Amazon River prawn, Macrobrachium amazonicum, Heller, 1862. Aquaculture, 453: 104-109. doi: 10.1016/j.aquaculture.2015. 11.038

Dutra, F.M., Freire, C.A., Dos Santos, A.M. V., Forneck, S.C., Brazão, C.C. \& Ballester, E.L.C. 2016b. Acute toxicity of nitrite to various life stages of the Amazon River prawn, Macrobrachium amazonicum, Heller, 1862. Bulletin of Environmental Contamination and Toxicology, 97: 619-625. doi: 10.1007/s00128-0161932-2

Furtado, P.S., Valenzuela, M.A., Rodriguez-Fuentes, G., Campos, B.R., Wasielesky Jr., W. \& Gaxiola, G. 2016. Chronic effect of nitrite on the rearing of the white shrimp Litopenaeus vannamei in two salinities. Marine and Freshwater Behaviour and Physiology, 49: 201211. doi: 10.1080/10236244.2016.1163837

González-Peña, M.C., Gomes, S.Z. \& Moreira, G.S. 2002. Effects of dietary fiber on growth and gastric emptying time of the freshwater prawn Macrobrachiurn rosenbergii (De Man, 1879). Journal of the World Aquaculture Society, 33: 441-447. doi: 10.1111/j. 1749-7345.2002.tb00023.x

Koroleff, F. 1976. Determination of nutrients. In: Grasshoff, K. (Ed.). Methods of seawater analysis.Verlag Chemie, Weinhein, pp. 117-181.

Kuhn, D.D., Smith, S.A., Boardman, G.D., Angier, M.W., Marsh, L. \& Flick Jr., G.J. 2010. Chronic toxicity of nitrate to Pacific white shrimp, Litopenaeus vannamei: impacts on survival, growth, antennae length, and pathology. Aquaculture, 309: 109-114. doi: 10.1016/j. aquaculture.2010.09.014

Li, Z.S., Ma, S., Shan, H.W., Wang, T. \& Xiao, W. 2019. Responses of hemocyanin and energy metabolism to acute nitrite stress in juveniles of the shrimp Litopenaeus vannamei. Ecotoxicology and Environmental Safety, 186: 109753. doi: 10.1016/j.ecoenv. 2019.109753

Maicá, P.F., Furtado, P.S., Martins, A.C.S., MirandaFilho, K.C. \& Wasielesky Jr., W. 2018. Effect of alkalinity on food consumption of juvenile pacific white shrimp reared in clear water and biofloc system. 
Boletim do Instituto de Pesca, 44: 1-9. doi: 10.20950/ 1678-2305.2018.222

Mallasen, M. \& Valenti, W.C. 2005. Larval development of the giant river prawn Macrobrachium rosenbergii at different ammonia concentrations and $\mathrm{pH}$ values. Journal of the World Aquaculture Society, 36: 32-41. doi: 10.1111/j.1749-7345.2005.tb00128.x

Marques, H.L.A. \& Moraes-Valenti, P.M.C. 2012. Current status and prospects of farming the giant river prawn (Macrobrachium rosenbergii (De Man 1879) and the Amazon River prawn Macrobrachium amazonicum (Heller 1862)) in Brazil. Aquaculture Research, 43: 984-992. doi: 10.1111/j.1365-2109.2011.03032.x

Miranda-Filho, K.C., Pinho, G.L.L., Wasielesky Jr., W. \& Bianchini, A. 2009. Long-term ammonia toxicity to the pink-shrimp Farfantepenaeus paulensis. Comparative Biochemistry and Physiology - Part C: Toxicology \& Pharmacology, 150: 377-382. doi: 10.1016/j.cbpc. 2009.06.001

Moraes-Valenti, P. \& Valenti, W.C. 2010. Culture of the Amazon River prawn Macrobrachium amazonicum. In: New, M.B., Tidwell, J.H., D'Abramo, L.R. \& Kutty, M.N. (Eds.). Freshwater prawns: biology and farming. Wiley-Blackwell, New Delhi, pp. 485-501.

Mugnier, C. \& Justou, C. 2004. Combined effect of external ammonia and molt stage on the blue shrimp Litopenaeus stylirostris physiological response. Journal of Experimental Marine Biology and Ecology, 309: 35-46. doi: 10.1016/j.jembe.2004.03.008

Ostrensky, A. \& Wasielesky Jr., W. 1995. Acute toxicity of ammonia to various life stages of the São Paulo shrimp, Penaeus paulensis Pérez-Farfante, 1967. Aquaculture, 132: 339-347. doi: 10.1016/0044-8486 (94)00343-M

Received: June 2, 2020; Accepted: August 4, 2021
Romano, N. \& Zeng, C. 2013. Toxic effects of ammonia, nitrite, and nitrate to decapod crustaceans: a review on factors influencing their toxicity, physiological consequences, and coping mechanisms. Reviews in Fisheries Science, 21: 1-21. doi: 10.1080/10641262. 2012.753404

Soares, R., Wasielesky, W., Peixoto, S. \& D'Incao, F. 2005. Food consumption and gastric emptying of Farfantepenaeus paulensis. Aquaculture, 250: 283290. doi: 10.1016/j.aquaculture.2005.04.072

Sokal, R.R. \& Rohlf, F.J. 2012. Biometry. W.H. Freeman and Company, New York.

Tomasso, J.R. 1994. Toxicity of nitrogenous wastes to aquaculture animals. Reviews in Fisheries Science, 2: 291-314. doi: 10.1080/10641269409388560

Wasielesky Jr., W., Bianchini, A., Castaño Sanchez, C. \& Poersch, L.H. 2003. The effect of temperature, salinity and nitrogen products on food consumption of pink shrimp Farfantepenaeus paulensis. Brazilian Archives of Biology and Technology, 46: 135-141. doi: 10.1590/S1516-89132003000100019

Wong, C.K., Chu, K.H., Tang, K.W., Tam, T.W. \& Wong, L.J. 1993. Effects of chromium, copper and nickel on survival and feeding behaviour of Metapenaeus ensis larvae and postlarvae (Decapoda: Penaeidae). Marine Environmental Research, 36: 63-78. doi: 10.1016/ 0141-1136(93)90082-B 